\title{
Cikal Bakal Total Quality Management (TQM) pada Perusahaan Jepang dan Implementasinya pada Perusahaan-Perusahaan di Indonesia
}

\author{
Puji Isyanto \\ Email: puji.isyanto@ubpkarawang.ac.id \\ Universitas Buana Perjuangan Karawang
}

\begin{abstract}
ABSTRAK
This study aims to examine total quality management in Japanese companies and their implementation in companies in Indonesia. This research method uses descriptive analysis method. Total Quality Management that binds to Japanese companies is inseparable from Kaizen culture, so that Japan applies the principle of customer satisfaction, Quality Function Development (QFD), employee empowerment and continuous improvement for the company. Product development carried out by Japanese companies is to meet market segments with international standards and on the quality side of the product. Continuous improvement in various fields, respect and teamwork are the keys to the success of Total Quality Management in Japanese companies. Japanese companies are identified as having long-term time horizons. Companies in Indonesia can adopt total quality management well so they can create excellence.
\end{abstract}

Keywords: total quality management, kaizen, continuous improvement.

\section{Latar Belakang}

Perkembangan perekonomian di dunia saat ini sangat pesat mengingat betapa banyaknya perusahaan-perusahaan baru yang mulai tumbuh dan berkembang tidak hanya di dalam negaranya saja, tetapi juga sudah mengepakkan sayap ke kancah internasional. Dari perkembangan perekonomian tersebut sudah pasti terdapat persaingan ekonomi di dunia dan antar perusahaan untuk menjadi perusahaan yang pertama dan mendapatkan perhatian konsumen di dunia. Hal ini mau tidak mau menuntut para pekerja yang ada di dalam sebuah perusahaan untuk berkembang atau mengembangkan ide pikiran mereka untuk bisa menjadi perusahaan yang semakin berkembang. Pekerjaan tersebut menuntut sebagian besar pada manajemen dalam mengantisipasi perkembangan perekonomian dunia.

Pasar dunia banyak dilirik oleh perusahaan-perusahaan di berbagai belahan dunia yang melihat peluang sektor tersebut sangat besar dan bisa mengubah perilaku konsumen dalam produk yang mereka tawarkan dan juga menjadi aktor dalam perekonomian dunia. Perlu diperhatikan juga mengenai kualitas produk yang ditawarkan tersebut kepada para konsumen. Perusahaan merupakan sebuah organisasi yang dijalankan oleh orang-orang yang berada di dalamnya untuk mencapai tujuan dari perusahaan. Dalam perusahaan sangatlah diperlukan adanya sebuah manajemen yang tepat dan mampu memberikan sebuah perbaikan-perbaikan begitu juga dalam sebuah manajemen mampu mengarahkan kepada arah kemajuan perusahaan dalam kegiatan ekonominya.

Untuk menghasilkan kualitas terbaik dibutuhkan usaha perbaikan yang terus-menerus dalam kemampuan karyawan, proses dan lingkungan. Jalan terbaik untuk memperbaiki kompenen-komponen tersebut secara terus-menerus adalah dengan mengimplementasikan Total Quality Management. Untuk meningkatkan penjualan dapat terjadi jika perusahaan mengimplementasikan secara benar Total Quality Management di seluruh aspek pada operasional perusahaan. Dibutuhkan secara terus-menerus pada semua bagian-bagian untuk diimplementasikan untuk melengkapi pelaksanaan terbaik perusahaan untuk mendapatkan 
kualitas produk dan pelayanan seperti yang dibutuhkan, dan hal tersebut nantinya akan berimbas kepada penjualan perusahaan. ${ }^{1}$

Horngren, et al (2000:8-9) menyatakan bahwa kunci sukses yang dapat mendorong perusahaan memiliki daya saing dalam kompetisi ditentukan oleh empat faktor, yaitu cost, quality, time, and innovation. ${ }^{2}$ Sistem akuntansi manajemen muncul untuk mempertahankan kinerja perusahaan dalam perubahan lingkungan ekonomi yang membawa kecenderungan utama pada orientasi konsumen, penerapan Total Quality Management (TQM), waktu sebagai elemen kompetitif, kemajuan dalam teknologi informasi, kemajuan dalam lingkungan produksi, pertumbuhan industri jasa, dan persaingan global (Hansen dan Mowen, 2000: 248). ${ }^{3}$

Munculnya Total Quality Management (TQM) telah menjadi salah satu perkembangan utama dalam praktik manajemen. TQM mulai diperkenalkan di AS sekitar tahun 1980, terutama dalam menanggapi tantangan kompetitif dari perusahaan Jepang. Pengakuan TQM sebagai keunggulan kompetitif telah meluas di seluruh dunia. ${ }^{4}$ Implementasi TQM di dalam perusahaan sangatlah penting untuk mendukung pencapaian standar kualitas dan menjaga konsistensi kualitas produk dan layanan produk. Membuat hal-hal tersebut untuk memperoleh pertambahan pelanggan, stabilitas profit dan percepatan pertumbuhan bisnis. Dalam upaya untuk tumbuh dan menjaga citra perusahaan, perhatian penuh pada kualitas akan memberikan dampak positif untuk peningkatan penjualan perusahaan. ${ }^{5}$

Jepang merupakan negara yang mengajukan konsep TQM yang kemudian diterima dan digunakan di berbagai belahan dunia. Konsep TQM telah banyak diadopsi oleh perusahaanperusahaan di berbagai negara, termasuk di Indonesia. William Edwards Deming menjadi nama yang memiliki reputasi sangat tinggi di Jepang. Kontribusinya sangat signifikan dalam kemajuan perekonomian Jepang. Dunia industri dan bisnis di Jepang berhasil mendunia, karena ajarannya tentang kontrol kualitas secara total. Pelajaran yang diajarkan oleh Deming adalah:

a. Menciptakan tujuan yang konstan dalam meningkatkan kualitas produk ahar kompetitif, unggul dalam persaingan

b. Berani berubah untuk mengambil tanggungjawab dalam memimpin serta menghadapi tantangan

c. Mengurangi ketergantungan akan pengawasan dengan membangun sistem produksi yang bermutu tinggi

d. Meminimalkan biaya keseluruhan dan membangun hubungan yang terpercaya dengan suplier

e. Membuat suatu sistem pendidikan untuk pengembangan diri para karyawan, pelatihan pekerjaan dan kepemimpinan

f. Mendorong supervisi yang membantu orang dan mesin kerja secara lebih baik

g. Menghilangkan kekhawatiran dan kecemasan agar orang-orang bekerja dengan efektif

\footnotetext{
1 The Influence of Total Quality Management (TQM) Applications to Sales Raising at PT. Kereta Api Indonesia (Persero) Bandung The 2nd Operations Area. ISBN: 978-979-99365-7-8. p.237

2 Horngren, Charles T., George Foster., Srikant M. Datar. 2000. Cost Accounting: A Managerial Emphasis. International Edition.

${ }^{3}$ Hansen, Don R. and Mowen Maryanne M. 2000. Management Accounting. Cincinnati Ohio: South-Western College Publishing.

${ }_{4}$ Prajogo D.I., A.S. Sohal (2000) TQM and innovation: A literature review and research framework, Technovation hal 539-558

5 The Influence of Total Quality Management (TQM) Applications to Sales Raising at PT. Kereta Api Indonesia (Persero) Bandung The $2^{\text {nd }}$ Operations Area. ISBN: 978-979-99365-7-8. p.237
}

67 Jurnal Manajemen \& Bisnis Kreatif Vol 4 No 2 
h. Menghilangkan penghalang antar departemen agar seluruh karyawan saling bekerja sama dengan baik.

Tulisan ini berusaha untuk memaparkan cikal bakal Total Quality Management (TQM) pada perusahaan Jepang dan implementasinya pada perusahaan di Indonesia, dengan menganalisis dari critical factor yang menunjang dan menghambat efektivitas implementasi tersebut.

\section{Kajian Teori}

\section{TQM (Total Quality Management)}

Menurut Soewarso Hardjosoedarmo (2004: 1), menjelaskan bahwa TQM adalah implementasi dalam memperbaiki kuantitatif utama dan jasa dalam pemasukan di organisasi, perbaikan pada seluruh proses penting dalam organisasi dan usaha meningkatkan pemenuhan kebutuhan yang konsumen butuhkan pada produk dan jasa dalam masa saat ini dan yang akan datang. Sedangkan menurut J. Paul Peter dan H. Donnelly dalam Wibowo (2007: 150) menjelaskan Total Quality Management is organization commintment for costumer satisfication with continue improvement to business process and product and services deliver, yang mana mengandung pengertian bahwa TQM adalah komitemen di dalam organisasi untuk memenuhi kepuasan konsumen dengan melanjutkan perbaikan dalam proses bisnis dan produk dan layanan jasa. Berdasarkan pada konsep pemikiran tersebut, maka TQM adalah alat bantu manajemen dalam perbaikan kualitas di dalam sebuah perusahaan untuk memaksimalkan daya saing organisasi secara berkelanjutan dalam produk, jasa, orang (pekerja), proses dan lingkungan dalam seluruh aspek penting dalam produk dan jasa untuk para konsumen.

Total Quality Management (TQM) merupakan paradigma baru dalam menjalankan bisnis yang berupaya memaksimumkan daya saing organisasi melalui fokus pada kepuasan konsumen, keterlibatan seluruh karyawan, dan perbaikan secara berkesinambungan atas kualitas produk, jasa, manusia, proses dan lingkungan organisasi (Krajewski and Ritzman, 2006) ${ }^{6}$. Menurut Sila et al. (2007) ${ }^{7}$ Total Quality Management (TQM) memainkan peranan yang sangat penting dalam meningkatkan kekuatan daya saing perusahaan. Di dalam pasar global yang berubah secara terus menerus, disamping pengiriman yang cepat (speed of delivery), kualitas produk juga menjadi salah satu elemen yang penting bagi perusahaan untuk dapat bersaing (competition). TQM adalah salah satu bentuk praktek manajemen terbaik dalam perusahaan yang menekankan paradigma kualitas secara menyeluruh dalam perusahaan.

TQM lebih menekankan pada produk dan konsumen (customer) bukan produksi massa, karyawan bertanggung jawab pada peningkatan kemampuan pabrik dalam menyelenggarakan berbagai aktivitas, namun tanggung jawab untuk mendeteksi perubahan-perubahan yang tidak sesuai dengan departemen pengendalian kualitas merupakan wewenang dari lini personalia.

Perbedaan TQM dan pendekatan bisnis lainnya adalah componen "bagaimana". Komponen tersebut terdiri dari 10 element menurut Goetsch dab Darvis dalam kutipan Fandy Tjiptono \& Anastasia Diana (2003: 15-18) ${ }^{8}$ adalah:

\section{Fokus konsumen}

\footnotetext{
${ }^{6}$ Krajewski, J. Lee and P. R. Larry, 2006, Operations Management Strategy and Analysis, Fifth Edition, Addison-Wesley Publising Company Inc.

7 Sila, I. 2007. Examining the effects of contextual faktors on TQM and performance through the lens of organizational theory: an empirical study, Journal of Operations Management, Vol. 25, No. 1, pp. 83-109.

8 Tjiptono, Diana, 2003, Total Quality Management, Andi Yogyakarta.p.15-18
} 
Dalam TQM, konsumen dari dalam maupun luar adalah penggerak. Eksternal konsumen memutuskan produk dan kualitas jasa yang mereka terima untuk mereka, dan internal konsumen memutuskan kualitas pada orang, proses dan lingkungan yang berhubungan dengan produk dan jasa

2. Kualitas obsesi

Di dalam organisasi yang mengimplementasikan TQM, menjaga kualitas dalam segala aspek tidaklah mudah. Lebih rumit jika konsumen merubah persepsi mereka akan kualitas. Merubah gaya hidup dan ekonomi dapat merubah persepsi kualitas mereka. Persepsi kosumen pada kualitas jasa lebih besar dalam pasar yang dapat membuat pemasukan lebih. Kualitas tinggi dalam jasa lebih dipilih oleh konsumen dan akan lebih menguntungkan.

3. Pendekatan empiris

Pendekatan empiris sangat penting dalam implementasi TQM, sebagian besar digunakan untuk desain kerja, proses pengambilan keputusan dan penyelesaian masalah dalam desain kerja. Data yang dibutuhkan untuk membuat tolak ukur pengawasan prestasi dan restrukturisasi.

4. Komitmen jangka panjang

TQM merupakan paradigma baru dalam bisnis. Dibutuhkan budaya perusahaan baru yang baik. Hal ini merupakan alasan mengapa komitmen jangka panjang sangat penting untuk perubahan budaya untuk implementasi kesuksesan TQM.

5. Tim kerja

Tim yang efektif dapat membuat rencana pertumbuhan dan membuat salusi untuk memecahkan permasalahan karyawan yang tidak ada sebelumnya. Kesuksesan tim bergantung pada masing-masing individu dan komitmen pada setiap anggota tim. Tim kerja dapat lebih sukses daripada bekerja sendiri.

6. Restrukturisasi sistem secara berkelanjutan

Manajemen kualitas tidak dapat dipisahkan dengan usaha berkelanjutan untuk merestrukturisasi dan merupakan dasar dari konsep Jepang, Kaizen, mencoba untuk mendapatkan operasi restrukturisasi berkelanjutan yang terbaik. Restrukturisasi secara berkelanjutan untuk mengidentifikasi tolak ukur terbaik dan yang dimiliki dalam proses kerja.

7. Pendidikan dan pelatihan

Dalam mengimplementasikan TQM dalam organisasi, pendidikan dan pelatihan yang baik harus diberikan kepada karyawan di dalam semua jenjang untuk memahami kualitas sistem manajemen, bagaimana mereka mempunyai peran dan bagaimana untuk bertanggungjawab dalam organisasi. Pelatihan adalah peran utama untuk digunakan organisasi dan kemampuan karyawan untuk menumbuhkan mengimplementasikan prinsip-prinsip TQM.

8. Kebebasan yang terkendali

Dalam TQM, melibatkan karyawan dan efisiensi yang digunakan dalam membuat keputusan dan pemecahan masalah merupakan elemen yang penting. Dan elemen tersebut dapat meingkatkan tanggungjawab diri sendiri dan karyawan dalam keputusan yang sudah dibuat dan memperkaya pandangan karena banyak pihak.

9. Kesatuan pada tujuan

TQM akan diimplementasikan dengan baik jika perusahaan mempunyai kesatuan tujuan. Setiap upaya dapat berfokus dalam satu tujuan. Bagaimanapun, persetujuan diantara Manajemen dan karyawan tidak penting.

10. Melibatkan efisiensi yang digunakan dan karyawan

Melibatkan efisiensi yang digunakan dan karyawan penting untuk diimplementasikan dalam TQM. Upaya untuk melibatkan karyawan memberikan dua manfaat, yaitu: 
a. Untuk meningkatkan kemungkinan keputusan yang baik, rancana yang baik dan keefktifan restrukturisasi

b. Untuk meningkatkan diri sendiri dan tanggungjawan pada keputusan dan melibatkan eksekutif karyawan. Fandy Tjiptono \& Anastasia Diana (2003).

Banker et al. (1993) ${ }^{9}$ menemukan bukti empiris bahwa frekuensi pelaporan ukuran kinerja manufaktur pada karyawan, terkait benar dengan implementasi Just-in-time, kerja sama tim, dan praktik TQM. Daniel \& Reitsperger $(1991)^{10}$ memberi bukti empiris yang mengindikasikan bahwa perusahaan mobil dan elektronik Jepang yang menggunakan strategi peningkatan kontinyu juga memberikan umpan balik yang lebih sering untuk memajukan kinerja. Locke and Latham (1990: 52) ${ }^{11}$ mengatakan bahwa dari proses pembelajaran, pelaporan ukuran kinerja yang lebih sering kepada karyawan membantu mereka mengembangkan strategi tugas efektif yang lebih cepat sehingga meningkatkan kinerja.

Perilaku produktif karyawan dapat ditingkatkan dengan menerapkan Manajemen Mutu Terpadu atau Total Quality Management (TQM) yang merupakan salah satu teknik yang sering digunakan oleh perusahaan manufaktur dalam rangka meningkatkan kinerjanya dan memaksimumkan daya saing perusahaan melalui perbaikan terus menerus atas produk, jasa, manusia, proses, dan lingkungannya. TQM juga mendukung semua karyawan mampu memberikan kontribusi yang cukup besar dengan kinerja yang baik dalam upaya mengubah diri dalam persaingan di era globalisasi ini. Seperti penjelasan Ajamsudin Benny (2006: 96), TQM mempunyai beberapa tujuan:

1. Untuk menciptakan kualitas produk dan jasa

Untuk mandapatkan keuntungan perushaan, perusahaan seharusnya membuat kualitas produk atau jasa, perusahaan membutuhkan penataan berkala. Penting untuk dilakukan oleh perusahaan untuk lebih menambah jumlah konsumen, dan meningkatkan penjualan perusahaan.

2. Menjamin kepemimpinan untuk menghindari kesalahan dan pemborosan

Orang berhadap pemborosan tidak akan berlanjut dalam waktu lama, karena dampak serius bagi perusahaan, salah satu dari hal tersebut adalah mengurangi jumlah penjualan perusahaan. Pemimpin perusahaan bekerja keras untuk meminimalkan kesalahan atau untuk suatu keputusan untuk menghindari penggunaan waktu dan manajemen sumber daya.

Adanya sumberdaya manusia dalam perusahaan sangat penting untuk mencapai tujuan yang telah ditentukan. Perusahaan menyadari untuk tidak bergantung pada sumber daya alam dan teknologi. Untuk bertahan dan berkembang, perusahaan bergantung kepada manajemen sumber daya manusia.

3. Menciptakan kompetisi produk dan jasa

Untuk menciptakan kompetisi produk dan jasa, perusahaan membutuhkan sistem produksi dan secara restrukturisasi berkelanjutan dan pemimpin pasar saham dan kepercayaan konsumen.

Menurut Blocher, Chen, Lin (2000:209), faktor-faktor yang mempengaruhi TQM terdiri dari (1) Berfokus kepada pelanggan, (2) Berusaha keras untuk melakukan perbaikan

\footnotetext{
9 Banker, R., G. Potter, dan R. Schroeder. 1993. Exporting manufacturing performance measures to worker: An empirical study. Journal of Management Accounting Research: 33-35.

10 Daniel, S., dan W. Reitsperger. 1991. Linking quality strategy with management control systems: Empirical evidence from Japanese industry. Accounting, Organizations and Society $17: 601-618$

11 Locke,E., dan G. Latham. 1990. Goal Setting Theory and Task performance". New York: Prentice Hall.
} 
berkelanjutan, (3) Melibatkan seluruh kekuatan kerja. Selain itu Goetsch dan Davis (1997:583) memberikan klasifikasi fase implementasi yang lebih rinci dan sistematis. Fase implementasi TQM dikelompokkan menjadi tiga fase yaitu fase persiapan, perencanaan dan pelaksanaan. Masing-masing fase terdiri atas beberapa langkah dimana waktu yang dibutuhkan untuk setiap langkah tergantung pada organisasi yang menerapkannya.

\section{Metodologi Penelitian}

Metode penelitian ini dengan menggunakan metode deskriptif analisis dengan pendekatan survey. Penelitian ini merupakan penelitian kualitatif yang menggunakan teknik observasi dan studi literatur. Observasi adalah suatu cara pengumpulan data dengan pengamatan langsung dan pencatatan secara sistematis terhadap obyek yang akan diteliti. Observasi dilakukan oleh peneliti dengan cara pengamatan dan pencatatan mengenai pelaksanaan praktek pengelolaan SDM pada perusahaan multinasional berbasis Jepang yang ada di Jakarta dan Bekasi, khususnya yang berkaitan dengan Total Quality Management (TQM). Sedangkan studi pustaka (literature study) merupakan segala usaha yang dilakukan oleh peneliti untuk menghimpun informasi yang relevan dengan topik atau masalah yang akan atau sedang diteliti. Informasi itu dapat diperoleh dari buku-buku ilmiah, laporan penelitian, karangan-karangan ilmiah, tesis dan disertasi, peraturan-peraturan, ketetapan-ketetapan, buku tahunan, ensiklopedia, dan sumber-sumber tertulis baik tercetak maupun elektronik lain.

Studi kepustakaan merupakan suatu kegiatan yang tidak dapat dipisahkan dari suatu penelitian. Teori-teori yang mendasari masalah dan bidang yang akan diteliti dapat ditemukan dengan melakukan studi kepustakaan. Selain itu seorang peneliti dapat memperoleh informasi tentang penelitian-penelitian sejenis atau yang ada kaitannya dengan penelitiannya. Dan penelitian-penelitian yang telah dilakukan sebelumnya. Dengan melakukan studi kepustakaan, peneliti dapat memanfaatkan semua informasi dan pemikiran-pemikiran yang relevan dengan penelitiannya. Untuk melakukan studi kepustakaan, perpustakaan merupakan suatu tempat yang tepat guna memperoleh bahan-bahan dan informasi yang relevan untuk dikumpulkan, dibaca dan dikaji, dicatat dan dimanfaatkan (Roth 1986) ${ }^{12}$.

\section{Hasil dan Pembahasan}

\section{TQM Merupakan Implementasi Panduan Spiritual Bagi Perusahaan-Perusahaan Jepang yang Berlandaskan pada Ajaran Buddhisme}

Beberapa penulis berpendapat bahwa Jepang secara unik mengadopsi TQM karena pengaruh dari nilai-nilai budaya dan sejarah industrialnya (Boje \& Winsor, 1993; Ishikawa, 1985). ${ }^{13}$ Untuk menguatkan argumen ini, pertama-tama akan dijelaskan peran spiritualitas Jepang dalam budaya Jepang. Walaupun terjadi perubahan radikal di negara ini pada 200 tahun terakhir, Jepang mempertahankan rasa hormat pada landasan agamanya, sehingga Buddhisme, Confucianisme, dan Shinto tetap menjadi sentral bagi praktek religius Jepang. Sebagian besar perusahaan Jepang yang modern biasanya dua atau bahkan tiga dari kepercayaan tersebut, dan

\footnotetext{
12 http://www.perkuliahan.com/apa-pengertian-studi-kepustakaan/\#ixzz38S9TsEC3

13 Poropat, Arthur \& John Keller. (n.d). Buddhism and TQM: An Alternative Explanation of Japan's Adoption of Total Quality Management. Department of Management, Griffith Business School, Griffith University, Australia.
} 
lebih diungkapkan pada partisipasi dalam ritual ketimbang filosofi/ teologi dan doktrin (Reader et al., 1993: 33) ${ }^{14}$.

Kepercayaan asli dari Jepang, Shinto, tetap menjadi kepercayaan bagi Kerajaan Jepang. Karakteristik utama dari Shinto adalah pada kepercayaan animism pada roh Kami yang mengisi dunia, yang menghuni segala kehidupan seperti pada gunung, batu, sungai, dan sebagainya (Reader, et al., 1993: 6). Kepercayaan ini mendominasi praktek Shinto, mengarah pada perhatian yang kuat dengan polusi dan ritual pemurnian (Reader, et al., 1993: 34). Filosofi China, yang dikenal di Barat sebagai Confusianisme masuk ke Jepang pada abad ke-enam dan pemahaman hirarkis mengenai tatanan social masih menjadi pengaruh utama pada etika social dan norma-norma hubungan dan perilaku sehari-hari (Varley, 1974: 39). Buddhisme, juga dating ke Jepang pada abad ke-enam ini, tetapi tidak menjadi agama yang popular hingga Periode Kamakura (1185-1333), ketika kemudian dipopulerkan sebagai agama yang menuju pada keselamatan. Buddhisme Jepang lebih menekankan pada pengajaran segala sesuatu untuk mendapatkan pencerahan atau darma Buddha, tidak hanya sumber daya dan karakter untuk mengikuti ritual khusus. Reinkarnasi lain dari Buddhisme Jepang adalah penekanannya pada belas kasihan sebagai tabungan untuk kehidupan di masa depan, melalui reinkarnasi atau menghindari penderitaan. Versi Buddha di Jepang disebut dengan Zen, yang menjadi salah satu bentuk dominan Buddhisme di Jepang (Reader, et al. 1993: 35-37).

Pada tingkat permukaan, terdapat hubungan parallel yang sangat jelas antara bagaimana pemikiran Buddhist dan TQM disajikan. Inti pemikiran dari Buddhisme tertuang pada empat nobel kepercayaan yang diperankan melalui delapan aras, dimana Deming mengatakannya sebagai "sistem pengetahuan yang mendalam", terbuat dari empat komponen (Deming, 1994) dan kumpulan yang lebih lebar untuk aksi ini dikenal dengan empat belas point (Deming, 1986). Penekanan umum dari disiplin tersebut adalah pada empat prinsip dasar yang dijadikan melalui daftar praktek-praktek yang menyajikan kemiripan bentuk pengajaran yang menarik. Akan tetapi, penggunaan daftar sederhana ini merupakan metode yang umum digunakan oleh guru di sepanjang sejarah untuk membantu mengingat. Tentunya, Deming bukanlah yang pertama menggunakan daftar tersebut, walaupun pemikiran Deming sangat dipengaruhi oleh pendekatan Jepang dalam mempresentasikan gagasannya. Misalnya, dalam beberapa tahun pertamanya di Jepang Deming berusaha untuk menemukan metode presentasi yang memudahkan orang Jepang untuk memahami dan mengadopsi mindset kualitas, seperti yang dipahaminya. Ketika hal ini dilakukan, 14 poin Deming tidak disajikan di Jepang tetapi murni dikembangkan untuk manajer-manajer Amerika (Noguchi, 1995). ${ }^{15}$ Sebagai konsekuensinya, kemiripan formal dari presentasi kualitas Deming dengan praktek pengajaran Buddhisme menarik bagi banyak orang, tetapi tidak mengejutkan. Kemiripan permukaan lainnya yang mirip antara Buddhisme dan TQM termasuk pengakuan adanya guru atau sang Pencerah (Buddha - Deming/ Juran), rasa bahwa terdapat hukum yang mendasari, aturan atau ajaran yang diikuti (Dharma/ Kepercayaan- Variasi, dll), dan mendorong respon kolektif dan kerjasama (Sangha/ Komunitas - Quality Circles, dll).

TQM berbagi basis yang sama, karakteristik yang tidak dapat diremehkan dengan Buddhisme. Untuk memulainya, TQM merupakan filosofi manajemen empiris, yang mendorong manajer untuk berfokus pada bukti langsung ketimbang pengetahuan yang diasumsikan (Kujala \& Lillrank, 2004) ${ }^{16}$. Point tersebut secara keseluruhan konsisten dengan

\footnotetext{
14 Reader, I., Andreasen, E., \& Stafansson, F. (1993). Japanese religions: Past and present. Honolulu: University of Hawaii Press.

15 Noguchi, J. (1995). The legacy of W. Edwards Deming. Quality Progress, 28(12), 35-37.

16 Kujala, J., \& Lillrank, P. (2004). Total quality management as a cultural phenomenon. Quality Management Journal, 11 (4), 43-55.
} 
Zen Buddhisme, yang mana diungkapkan kembali segala bentuk mediasi dogmatis (atau intelektual) antara pengalaman dan pengetahuan. Dengan demikian, posisi filosofi dasar dari Zen Buddhisme dan TQM memiliki basis yang mirip dengan bagaimana seseorang datang untuk mengetahui kealamian suatu hal, dan yang meragukan posisi dogmatis. Dalam budaya Jepang, ketidaksempurnaan hidup, pandangan bahwa tidak ada yang dapat memuaskan adalah asumsi dasar. Hal ini diimplikasikan oleh nobel pertama dari empat nobel Buddhist penderitaan tiada akhir. Penerimaan kepercayaan ini, tidak dipandang sebagai nihilistik, tetapi lebih dianggap sebagai bukti untuk menyuburkan seseorang. Aktivitas lain yang berkaitan adalah Kaizen (continous improvement), yang dihubungkan secara langsung dengan Zen Buddhisme. Zen dalam Kaizen merujuk pada praktek hal yang baik atau manfaat dengan cara yang impersonal, sementara kai merujuk pada usaha untuk menciptakan perubahan. Dengan demikian, Kaizen berbicara tentang perbaikan, tetapi biasanya berarti usaha yang sedang dilakukan untuk mencapai manfaat impersonal (Lincoln, 1989) ${ }^{17}$. Dalam mengejar suatu impersonal virtue, menurut Zen menekankan pada kerja keras yang berkesinambungan untuk mencapai pencerahan (Stupak, 1999: 428), tetapi masih tetap konsisten dengan penekanan TQM. Ciri-ciri utama manajemen Kaizen antara lain lebih memperhatikan pada proses produksi dan bukan hasil, manajemen fungsional silang dan menggunakan lingkaran kualitas dan peralatan lain untuk mendukung peningkatan yang terus menerus (Cane, 1998:27).

Kaizen selalu sejalan seiringan dengan Total Quality Management (TQM). Bahkan sebelum filosofi Total Quality Management ini terlaksana atau sebelum sistem mutu dapat dilaksanakan dalam suatu perusahaan maka filosofi ini tidak akan dapat dilaksanakan sehingga perbaikan secara terus menerus (Just In Time) ini adalah usaha yang melekat pada filosofi Total Quality Managment itu sendiri.

Kunci keunggulan perusahaan Jepang adalah sangat unggul dalam persaingan salah satu kemampuannya adalah menghilangkan pemborosan dan menghindari berbagai kesulitan sedangkan AS sebaliknya mengalami kesulitan dalam menghemat Sumber Daya Alam yang memang sangat melimpah bila dibandingkan Jepang sehingga istilah perbaikan mutu secara terus menerus (Just in time) tidak berlaku bagi manajemen Amerika tapi lebih cenderung just in case.

\section{Pola Pikir TQM pada Perusahaan Jepang}

\section{a. Mutu No.1}

Mutu menjadi prioritas utama, tanpa mutu tidak ada pembeli. Tanpa pembeli perusahaan tidak akan untung. Tanpa keuntungan perusahaan akan bangkrut, sehingga mutu harus menjadi perhatian yang utama

\section{b. Siklus manajemen (PDCA, SDCA)}

Plan-Do-Check-Action digunakan sebagai sarana peningkatan mutu produk. Dengan memutar siklus PDCA maka akan banyak sekali Kaizen yang bisa dihasilkan. Ketika mutu sudah dicapai pada taraf tertentu, maka dilakukanlah suatu sistem standarisasi agar tidak terjadi kemunduran dengan siklus Standard-Do-Check-Action

\section{c. Manajemen berdasarkan fakta.}

Manajemen harus menggunakan fakta atau data yang riil, bukan atas dasar kira-kira atau opini semata.

\footnotetext{
17 Lincoln, J. R. (1989). Employee work attitudes and management practice in the US and Japan. California Management Review (Fall), 89-106.
} 


\section{d. Manajemen proses.}

Mutu dibuat di dalam proses, maka harus ada manajemen proses, mutu tidak dibuat dengan inspeksi, mutu dibuat ketika produk sedang dibuat. Proses yang baik akan menghasilkan barang yang baik dan apabila proses yang buruk akan menghasilkan barang yang buruk pula.

\section{e. Orientasi pada market in.}

Market-in mempertimbangkan mutu atas permintaan pasar. Apa yang pasar mau saja yang akan dipenuhi, dengan jumlah produk yang sedikit dalam jumlah variasi produk yang banyak.

\section{f. Orientasi pada prioritas.}

Menyadari bahwa ada banyak masalah dan masalah utama saja yang fokus untuk dilakukan perbaikan. Dengan berorientasi pada prioritas maka segala tindakan perbaikan akan lebih bermanfaat dan tepat sasaran.

\section{g. Pelanggan}

Perusahaan pantang membuat pelanggan kecewa, mereka tidak ingin merepotkan orang lain. Dengan menanamkan pola pikir bahwa proses berikutnya adalah pelanggan, maka dengan demikian akan sangat menyesal apabila ada masalah di dalam proses produksi. Terdapat tiga proses utama dalam produksi dalam perusahaan yaitu proses sebelum proses, proses selama proses, proses setelah proses selesai. Dengan tahap ini maka sebenarnya akan ada banyak proses inspeksi yang double antara proses, sehingga mutu bisa segera diketahui jika ada masalah.

\section{h. Standarisasi}

Standarisasi digunakan untuk upaya mencegah kemunduran level mutu. Standarisasi akhirnya dijadikan budaya baru bagi orang perusahaan agar mutu benar-benar dijaga, meskipun dahulu perusahaan lebih banyak menutup diri, kecemasan akan rahasia sukse perusahaan ditiru oleh perusahaan lain.

\section{Langkah penting Total Quality Management Jepang}

\section{Kaizen}

Proses Perbaikan yang Berkelanjutan. Perusahaan selalu berusaha meningkatkan efektifitas, efisiensi, dan produktifitas kerja mereka. Sesuai artinya, filosofi dari Kaizen adalah melaksanakan perbaikan atau peningkatan yang berkesinambungan. Adapun realisasinya dalam suatu perusahaan Setiap Karyawan di semua level di dalam organisasinya dapat berpartisipasi dalam Kaizen, mulai dari Manajemen Puncak hingga ke level bawah, hal ini bertujuan untuk pengembangan perusahaan ke arah yang lebih baik. Format Kaizen dapat berupa perseorangan, sistim saran, kelompok kecil, atau kelompok besar. sampai bawahan atau istilahnya way of life perusahaan. Beberapa point penting dalam proses penerapan Kaizen yaitu :

a. Konsep 3M (Muda, Mura, dan Muri) dalam istilah Jepang. Konsep ini dibentuk untuk mengurangi kelelahan, meningkatkan mutu, mempersingkat waktu dan mengurangi atau efsiensi biaya. Muda diartikan sebagai mengurangi pemborosan, Mura diartikan sebagai mengurangi perbedaan dan Muri diartikan sebagai mengurangi ketegangan. 
b. Gerakkan 5S (Seiri, Seiton, Seiso, Seiketsu dan Shitsuke) atau 5R. Seiri artinya membereskan tempat kerja. Seiton berarti menyimpan dengan teratur. Seiso berarti memelihara tempat kerja supaya tetap bersih. Seiketsu berarti kebersihan pribadi. Seiketsu berarti disiplin, dengan selalu mentaati prosedur ditempat kerja. Di Indonesia 5S diterjemahkan menjadi 5R, yaitu Ringkas, Rapi, Resik, Rawat dan Rajin

c. Konsep PDCA dalam KAIZEN. Setiap aktivitas usaha yang kita lakukan perlu dilakukan dengan prosedur yang benar guna mencapai tujuan yang kita harapkan. Maka PDCA (Plan, Do, Check dan Action) harus dilakukan terus menerus.

d. Konsep 5W $+1 \mathrm{H}$. Salah satu alat pola pikir untuk menjalankan roda PDCA dalam kegiatan KAIZEN adalah dengan teknik bertanya dengan pertanyaan dasar $5 \mathrm{~W}+$ $1 \mathrm{H}$ (What, Who, Why, Where, When dan How).

\section{Atarimae Hinshitsu}

Nilai fungsi (agar semua berjalan sebagaimana mestinya). Setiap benda yang diciptakan mempunyai fungsi tertentu sehingga memberi kegunaan maksimal. Misalnya, sebuah sepeda motor berfungsi untuk mengantarkan pengendaranya dari satu tempat ke tempat lain. Jika tidak bisa dinyalakan mesinnya, sepeda motor itu dikatan tidak berfungsi.

\section{Kansei}

Pengamatan perilaku konsumen untuk peningkatan kualitas produk. Dalam dunia bisnis, perusahaan-perusahaan mengamati bagaimana perilaku konsumen dalam menggunakan produk atau jasa mereka. Setiap konsumen mempunyai kecenderungan yang berbeda. Namun mereka selalu cenderung untuk terus menggunakan produk atau jasa yang efektif dan efisien dibanding yang tidak.

\section{Miryokuteki hinshitsu}

Nilai keindahan (di samping nilai fungsi). Mempunyai fungsi saja tidak cukup bagi sebuah produk untuk mempunyai nilai lebih. Jika tidak berfungsi maka produk tersebut tidak ada gunanya atau rusak. Fungsi sudah menjadi sebuah standar. Sepeda motor sebenarnya sudah cukup untuk menjadi sebuah alat transportasi selama ia bisa menggerakkan mesinnya dan mengangkut penumpangnya.

\section{Kepuasan Pelanggan, Quality Function Development (QFD), Pemberdayaan Karyawan, Perbaikan Berkesinambungan dalam TQM perusahaan Jepang}

\section{Kepuasan Pelanggan}

Kepuasasn pelanggan dapat diartikan sebagai perbedaan antara harapan dan kinerja atau hasil yang dirasakan. Kepuasan pelanggan akan tercipta jika pelanggan merasakan output atau hasil pekerjaan sesuai dengan harapan, atau bahkan melebihi harapan pelanggan. Semua usaha manajemen dalam , pada dasarnya mempunyai suatu tujuan, yaitu untuk memuaskan pelanggan. Kepuasan pelanggan sangat diharapkan oleh perusahaan karena akan memberi manfaat, antara lain terjalinnya hubungan yang erat antara perusahaan dengan pelanggan sehingga memberi peluang untuk pembelian ulang. Dengan kepuasan pelanggan, reputasi perusahaan menjadi baik dan dapat membentuk opini publik yang menguntukan perusahaan akan semakin besar. Pelanggan adalah mereka yang dapat menentukan kualitas. Untuk mengetahui apakah 
produk yang dihaslikan suatu perusahaan dapat sesuai dengan kualitas yang diharapkan pelanggan, perlu dilakukan pemantauan dan pengukuran terhadap kepuasan pelanggan.

\section{Quality Function Develoyment (QFD)}

Quality Function Develoyment (QFD) merupakan suatu metode perencanaan dan pengembangan produk terstruktur, yang memungkinkan tim pengembangan produk untuk menentukan secara jelas keinginan dan kebutuhan konsumen dan kemudian melakukan evaluasi secara sistematis tentang kemampuannya dalam menghasilkan produk untuk memuaskan konsumen. Tujuan dikembangkannya konsep QFD adalah untuk menjamin bahwa produk yang telah dihasilkan perusahaan memberikan kepuasan bagi pelanggan, dengan jalan memperbaiki tingkat kualitas dan kesesuaian maksimal pada setiap tahap pengembangan produk. Karena pada dasarnya suatu produk yang telah dihasilkan dengan sempurna bukan berarti telah memberikan kepuasan bagi pelanggan. Hal terpenting adalah apakah pelanggan tersebut membutuhkan produk sesuai dengan keinginannya. Manfaat dari Quality Function Develoyment antara lain sebagai berikut:

a. Focus pada pelanggan. QFD memerlukan masukan dan umpan balik dari pelanggan. Informasi berupa masukan dan umpan balik tersebut merupakan persyaratan pelanggan yang spesifik. Dari informasi ini data diketahui seberapa jauh perusahaan telah memenuhi kebutuhan pesaingnya, begitu pula informasi mengenai perusahaan pesaingnya.

b. Efisiensi waktu. Dengan telah teridentifikasi persyaratan pelanggan QFD dapat mengurangi waktu dalam pengembangan produk.

c. Berorientasi teamwork (kerja sama tim). Karena keputusan dalam proses berdasarkan consensus dan melalui diskusi, maka setiap individu memahami posisinya di dalam tim. Hal itu dapat memperkokoh kerja sama tim.

d. Berorientasi pada dokumentasi. Dokumen mengenai semua data yang berhubungan dengan segala proses dan perbandingan persyaratan pelanggan merupakan hasil dari proses QFD. Dokumen dapat berubah setiap ada informasi baru.

\section{Pemberdayaan Karyawan}

Masalah ketenagakerjaan yang sering terlupakan oleh manajemen adalah pemberdayaan karyawan. Sebagian kalangan pengusaha berpandangan bahwa setelah memperoleh tenaga kerja dengan tingkat pendidikan danketerampilan memadai, kemudian melakukan pelatihan dan memberi upah/ gaji yang layak secara otomatis akan diperoleh hasil yang memuaskan. Ternyata pandangan demikian tidak benar. Tidak selamanya seseorang yang digaji dengan cukup tinggi akan puas dengan pekerjaaanya. Banyak sekali faktor yang menyebabkan karyawan merasa puas dan senang bekerja pada suatu organisasi. Sangat penting kiranya manajemen mengetahui dan meyesuaikan antara keinginan karyawan dengan tujuan perusahaan. Salah satu keinginan karyawan dalam suatu organisasi adalah dilibatkan dan diberdayakannya mereka pada semua tingkat organisasi dalam proses pemecahan masalah.

Pemberdayaan dapat diartikan sebagai pelibatan karyawan dalam suatu proses pembuatan keputusan dan pemecahan masalah. Pemberdayaan tidak sekedar memberi masukan-masukan atau umpan balik tetapi juga dilibatkan dalam mempertimbangkan dan menindaklanjuti masukan tersebut. TQM sendiri merupakan konsep pelibatan dan pemberdayaan karyawan. Berbeda dengan manajemen partisipatif di mana manajer hanya meminta bantuan karyawan berupa masukan-masukan yang akan dipergunakan dalam pengambilan keputusan dan pemecahan masalah, pemberdayaan karyawan mengarahkan para karyawan membantu dirinya sendiri, sesama rekan karyawan dan 
perusahaan. Dengan pemberdayaan karyawan para karyawan merasa dihargai dan diperlukan bukan sebagai robot atau mesin, melainkan sebagai manusia yang mempunyai akal pikiran dan kempuan untuk bekerja dengan baik.

Hubungan industri pada perusahaan Jepang cenderung mengutamakan adanya serikat pekerja, dan hal tersebut sangat disambut antusias oleh karyawannya. Diskusi antara manajemen dengan karyawan yang disebut dengan Roushi Kyougi juga dilakukan untuk mengutarakan pendapat, kebijaksanaan, serta ikatan dalam perusahaan. Selain itu juga terdapat collective bargaining (forum) yang dilakukan setiap tahun, yang disebut dengan Dantai Koushou, yang mana dapat memupuk sense of belonging, hubungan sosial, serta tatanan sosial.

\section{Perbaikan Berkesinambungan}

Salah satu unsur paling fundamentalis dari TQM adalah perbaikan berkesinambungan, atau dalam istilah Jepang dikenal dengan nama Kaizen. Pokok strategi Kaizen adalah menyadari bahwa manajemen harus berusaha untuk memuaskan pelanggan dan memenuhi kebutuhan pelanggan bila ingin tetap hidup dan memperoleh laba. Penyempurnaan dalam bidang mutu, biaya, dan penjadualan (untuk memenuhi kebutuhan akan volume barang dan hasil produksi) sangat penting. Titik awal perbaikan ialah menyadari akan adanya masalah. Bila tidak menyadari akan adanya masalah, maka tidak akan menyadari pula adanya kebutuhan akan perbaikan. Perasaan cepat puas atas apa yang telah tercapai merupakan musuh besar dari perbaikan ini.

Bangsa Jepang tidak memulai kebangkitannya dengan suatu sistem yang canggih dan tidak ingin mencapai sesuatu dengan jalan pintas. Mereka membangun kekayaan dengan sederhana, seperti dengan sistem $5 \mathrm{~S}$ yaitu untuk memelihara kondisi yang mantap dan memelihara kebiasaan yang diperlukan untuk melaksanakan pekerjaan dengan baik. Nilai-nilai asli Jepang yang hingga ini masih diterapkan pada perusahaan-perusahaan MNC Jepang adalah 5S, yaitu Seiri, Seiton, Seiso, Seiketsu, dan Shitsuke, yang akan dijelaskan sebagai berikut ${ }^{18}$ :

\section{a. SEIRI}

\section{(Arti: Organize/Organisir; konversi dalam Bahasa Inggris: Sort atau Sorting)}

Lingkungan kantor di Jepang yang super-sibuk sangat rentan akan penumpukan dokumen, kertas-kertas, dan media kerja lainnya. Masalah serius yang dapat terjadi ketika dokumen menumpuk adalah banyaknya pekerjaan, pengajuan, atau approval yang tertunda. Lama-kelamaan, akan sulit untuk memisahkan antara dokumen yang membutuhkan aksi lebih lanjut, dan mana yang sudah tidak diperlukan dan harus dibuang. Tumpukan inilah yang akan menghalangi karyawan untuk bekerja secara efisien.

Prinsip dasar seiri adalah memastikan bahwa tumpukan semacam itu tidak terjadi. Sangat penting untuk memilah sejak awal, mana yang diperlukan untuk disimpan dan mana yang tidak. Perusahaan Jepang melakukan SEIRI dengan memberikan tanda (dapat berupa label warna, kotak wadah, dan sebagainya) yang akan memberi petunjuk, dokumen/barang apa yang harus disimpan dan mana yang harus dibuang.

\section{b. SEITON}

(Arti: Neatness/Kerapian; konversi dalam Bahasa Inggris: Set in Order atau Simplify)

\footnotetext{
18 Masaaki Imai. 1998. Genba Kaizen : Pendekatan Akal Sehat, Berbiaya Rendah Pada
} Manajemen. Jakarta, Pustaka Brinaman Pressindo. 
Setelah semua dokumen dan benda disortir (mana yang disimpan dan mana yang dibuang), maka kini saatnya untuk bergerak ke tahap seiton. Disadari atau tidak, kita banyak membuang jam-jam produktif di kantor untuk mencari atau menjangkau berbagai barang yang berbeda yang diperlukan untuk pekerjaan. Untuk menghindarinya, perusahaan Jepang memastikan barang dan dokumen di kantor mereka harus ditata sedemikian rupa, berdasarkan kepentingan/frekuensi penggunaannya. Mereka meletakkan barang yang sering dipakai di tempat yang dekat dengan workstation sehingga mudah dijangkau, dan barang-barang yang jarang digunakan diletakkan di tempat penyimpanan yang lebih jauh.

Selain meletakkan barang berdasarkan frekuensi penggunaannya, perusahaan Jepang juga memastikan bahwa penyusunan barang serta dokumen tersebut harus dilakukan sedemikian rupa sehingga mudah dikeluarkan/diambil; tidak perlu usaha ekstra untuk memindahkan/mengeluarkan barang lain yang tidak diperlukan lalu mengembalikannya lagi. Mereka benar-benar memastikan efisiensi waktu dan tenaga. Posisi ideal penyimpanan adalah tempat yang masih berada diantara mata dan pinggul manusia; tidak terlalu tinggi atau rendah.

\section{c. SEISO}

\section{(Arti: Cleaning/Membersihkan; konversi dalam Bahasa Inggris: Shine atau Sweep)}

Di Jepang, orang memiliki prinsip bahwa akan lebih sulit untuk mengembalikan sesuatu benda kepada kondisi prima setelah beberapa lama terabaikan, dibanding menjaga kondisi barang tersebut tetap prima. Menjaga setiap benda tetap berada dalam kondisi terbaik mereka akan memperpanjang waktu pakai dari barang-barang tersebut dan bahkan dapat mempermudah pekerjaan lainnya. Perusahaan Jepang melakukan seiso; memastikan setiap benda berada dalam kondisi terbaiknya sedapat mungkin. Mereka melakukannya dengan menggabungkan rutinitas pembersihan dan perawatan (maintenance).

\section{d. SEIKETSU}

\section{(Arti: Standardisasi; konversi Bahasa Inggris: Standardize)}

Tanpa adanya struktur, mungkin tidak banyak hasil yang telah didapat dari setiap inisiatif yang pernah dilakukan akan mampu bertahan. Mereka menyadari, tanpa adanya struktur dan proses, hasil positif yang telah didapat akan cepat terkikis, sementara banyak kebingungan yang terjadi, yang akan melempemkan inisiatif 5S. Karena itulah, mereka melakukan standardisasi dan dokumentasi proses yang akan memastikan berjalannya SEIRI, SEITON, dan SEISO secara konsisten dengan adanya SOP.

\section{e. SHITSUKE}

\section{(Arti: Disiplin; konversi Bahasa Inggris: Sustain / Self-discipline)}

Memulai inisiatif yang positif bisa jadi merupakan perkara mudah, namun mempertahankan konsistensi dan hasil dari inisiatif tersebut bisa jadi merupakan aspek yang paling sulit. Untuk meraih SHITSUKE, perusahaan Jepang mengintegrasikan aktifitas dan penataan $5 \mathrm{~S}$ kepada proses bisnis untuk memantau kepatuhan setiap departemen dan sendi organisasi terhadap 5S.

Banyak perusahaan Jepang menggunakan strategi rewarding, yaitu memberikan penghargaan kepada orang-orang yang telah berperan dalam implementasi $5 \mathrm{~S}$ sebagai aktifitas harian, disamping melakukan aktifitas dan pekerjaan mereka 
sendiri. Organisasi harus mencari cara agar integrasi 5S menarik untuk memastikan keterlibatan seluruh stakeholder.

\section{Implementasi TQM pada Perusahaan-Perusahaan di Indonesia}

\section{Critical Factors yang Memberikan Kontribusi bagi Keberhasilan TQM di Indonesia}

Putri dan Yusof (2008) mengajukan faktor-faktor penting yang memberikan kontribusi bagi keberhasilan quality engineering bagi industri otomotif di Malaysia dan Indonesia, yaitu:

1. Management Responsibility

Perencanaan kualitas strategis (kejelasan dan orientasi visi/ kebijakan kualitas), yang berarti kekompakan tim manajemen senior yang berkomitmen untuk memberikan kepuasan pelanggan dan mengkomunikaskan visi dengan cara yang dapat memobilisasi seluruh karyawan terhadap tujuan organisasi. Tanggung jawab awal adalah pada pengembangan kebijakan kualitas perusahaan, yang mengintegrasikan pernyataan misi/ visi, sasaran strategis dan kebijakan perusahaan.

2. Pengelolaan sumber daya

Organisasi harus mengidentifikasi dan menyediakan seluruh sumber daya yang diperlukan untuk mencapai rencana kualitas. Sumber daya ini, termasuk personel yang terlatih dan memenuhi kualifikasi, fasilitas, peralatan, dan lingkungan kerja yang memenuhi kebutuhan konsumen. Putri dan Yusof (2008) memandang manajemen sumber daya sebagai salah satu faktor penting yang akan mempengaruhi keberhasilan implementasi quality engineering $(\mathrm{QE})$. Faktor penting ini dipisahkan menjadi tiga sub faktor, yaitu:

a. Sumber daya yang berkaitan dengan teknologi dan produksi (misalnya: fasilitas dan peralatan);

b. Sumber daya yang berkaitan dengan pemodalan/ finansial; dan

c. Sumber daya yang berkaitan dengan informasi dan komunikasi.

3. People Management

Keterlibatan dan pemberdayaan merujuk bahwa komitmen dan kepemimpinan manajemen sendiri, walaupun sangat fundamental tetapi tidak cukup bagi keberhasilan QE. Hal ini memerlukan keterlibatan karyawan pada semua fungsi, dan pada semua tingkatan. Keterlibatan dan partisipasi karyawan terbukti bekerja pada banyak organisasi sebagai salah satu sarana untuk meningkatkan dan mencapai kualitas. Ketika karyawan semakin berkomitmen dan terlibat pada perwujudan visi, nilai, dan sasaran kualitas, pemberdayaan akan menjadi semakin diperlukan. Keterlibatan karyawan secara spesifik berkaitan dengan bagaimana karyawan mendorong dan memungkinkan mereka sendiri melakukan peningkatan kerja di luar tanggung jawab pekerjaan rutin mereka.

Teamwork adalah salah satu fitur penting dari keterlibatan, dan tanpa hal tersebut, akan ditemukan kesulitan dalam memperoleh komitmen dan partisipasi karyawan di seluruh organisasi (Dale, 2003). Juran dan Gyrna (1980) memberikan contoh dari praktek teamwork, yang disebut Quality Control Circle (QCC).

4. Kualitas dalam Desain dan Proses

Manajemen proses/ prosedur operasi merupakan sub-faktor yang menekankan pada nilai tambah terhadap proses, meningkatkan tingkat kualitas dan meningkatkan produktivitas per karyawan. Motwani (2001) berpendapat bahwa terdapat berbagai macam taktik yang menekankan pada pencapaian sub-faktor ini seperti memperbaiki 
metode work center dan memasang proses yang terkontrol oleh operator sehingga menghasilkan biaya per unit yang lebih rendah, mencapai kaizen (continuous improvement), menurunkan biaya material handling, mempromosikan desain untuk program manufaktur, serta mencapai aliran proses yang singkat.

5. Pengukuran, Analisis dan Perbaikan

Perusahaan harus mencakup penerimaan yang kuat dan maintenance pengukuran kualitas total dan rencana benchmarking. Program kualitas harus mengukur persentase jumlah bagian yang menyimpang dari yang dapat diterima untuk mencegah terjadinya kerusakan / kesalahan terulang. Teknik pengukuran juga harus dapat memonitor tingkat kualtias supplier dengan menggunakan proses control statistic (statistical process control/ SPC) untuk menurunkan variabilitas proses dan menghitung biaya kualitas (Motwani, 2001). Menurut Yusof dan Aspinwall (1999, 2000) dalam Putri \& Yusof (2008), pengukuran berbeda dikumpulkan, misalnya jumlah barang yang reject, parts per million dan biaya kualitas, untuk monitoring dan peningkatan kualitas kinerja. Datadata tersebut sebagian besar disajikan dalam bentuk bar charts, line graphs, dan diagram pareto. Berbagai macam quality tools dan teknik digunakan dalam proses yang berbeda. Misalnya, failure mode and effect analysis (FMEA) dan desain eksperimen terutama digunakan dalam desain dan proses pengembangan.

6. Manajemen Pemasok (Supplier)

Banyak peneliti berpendapat bahwa perusahaan harus membangun supply chain partnership untuk memotivasi supplier dalam menyediakan material yang diperlukan untuk memenuhi harapan pelanggan (Lau \& Idris, 2001; Thiagarajan, et al. 2000) dalam Putri \& Yusof (2008). Lebh lagi, dengan memiliki supply chain management yang efektif dapat memberikan kontribusi bagi kinerja kualitas dalam banyak cara. Evaluasi pemasok secara berjala dapat membangu organisasi berbagi informasi dan meningkatkan mutual understanding. Kemitraan jangka panjang/ hubungan dengan supplier juga membantu pihak-pihak yang terlibat untuk memecahkan masalah dengan supplier dan juga membantu pihak-pihak yang terlibat untuk memecahkan masalah kualitas serta berinvestasi dalam usaha peningkatan kualitas. Supplier partnership merupakan cara untuk mengembangkan hubungan dengan supplier guna memastikan bahwa mereka memahami kebutuhan dan keperluan spesifik pelanggan. Motwani (2001) berpendapat bahwa kemitraan supplier/ vendor seharusnya didasarkan pada program kualitas dan dokumentasi progress yang dapat diterima terhadap peningkatan yang berkesinambungan dalam kualitas.

7. Fokus pada Pelanggan

Faktor ini melihat pada informasi yang dapat berguna untuk meningkatkan kepuasan pelanggan dan bagaimana kinerjanya dibandingkan dengan organisasi serupa. Informasi ini dapat digunakan untuk perbaikan lebih lanjut untuk membangun pemahaman lingkungan dimana perusahaan beroperasi di dalamnya (Lau dan Idris, 2001) dalam Putri \& Yusof (2008). Motwani (2001) berpendapat bahwa customer service seharusnya melayani dua area utama: internal customer service dan external customer assurance. Komponen-komponen dari internal customer service plan termasuk penyediaan penyelesaian pekerjaan yang tepat waktu dan dapat diandalkan, menyajikan perbaikan atau saran penghematan biaya bagi manajemen dan emmberikan kewenangan pada karyawan untuk solusi yang dapat diimplementasikan sendiri, crosstraining karyawan untuk penguasaan pekerjaan, serta menyediakan technical training yang memadai.

$\underline{\text { Faktor Penghambat Efektivitas Implementasi TQM di Indonesia }}$ 
Amar \& Zain (2001) melakukan penelitian pada 364 perusahaan manufaktur yang dipilih dari Direktori Industri Manufaktur Indonesia (BPS, 1999), yang menurut klasifikasinya terdiri atas makanan, minuman dan rokok; tekstil,pakaian \& kulit; kayu \& produk kayu; kertas, cetak, dan penerbitan; kimia, pelumas, batubara, karet \& produk plastik; produk mineral nonmetalik; baja; produk baja pabrikasi, mesin \& peralatan; serta industri manufaktur lainnya. Analisis data tersebut menyingkapkan 11 faktor yang memberikan kontribusi mengikus upaya implementasi TQM dalam perusahaan. Faktor-faktor yang dimaksud adalah masalah SDM, sikap terhadap kualtias, budaya, hubungan antar departemen, material, mesin dan peralatan, informasi yang berkaitan dengan kualitas, metode, pelatihan, dan pembiayaan.

Di Indonesia, tingkat pendidikan, keterampilan, dan pemahaman tentang manajemen kualitas serta asimilasi budaya kerja yang berkualitas masih rendah. Disamping point-point tersebut, terdapat masalah-masalah seperti konformasi prosedur, moral pekerja yang rendah, aksi industri, turnover karyawan yang tinggi serta absentisme membuat implementasi TQM di Indonesia tidak dapat berjalan dengan mulus. Meneruskan dari respon di atas, terdapat perdebatan kecil mengapa kualitas kinerja pekerja di Indonesia masih tertinggal di belakang negara-negara Asia, khususnya Jepang. Studi yang dilakukan oleh Tamimi \& Sebastianelli (1998) dan Salegna \& Fazel (2000) juga menempatkan masalah SDM sebagai faktor kontributor tunggal yang menentukan efektivitas implementasi TQM di Indonesia.

Faktor sumber daya penting lainnya dalam sampel yang disurvey oleh Amar \& Zain (2001) adalah kondisi mesin yang buruk yang digunakan dalam proses produksi. Masalahmasalah seperti downtime yang tinggi, penggunaan mesin yang sudah usang dan tidak layak, serta koordinasi pengadaan suku cadang peralatan yang buruk membuat program maintenance yang selanjutnya berpengaruh pada proses produksi menjadi tidak efisien.

Manajemen sendiri, ditemukan dapat menghalangi implementasi TQM sehingga mengarah pada kegagalan (Amar \& Zain, 2001). Hal ini berasal dari kurangnya komitmen pemimpin untuk mengimplementasikan TQM, dimana di Indonesia figur pemimpin masih dijadikan panutan/ teladan penting yang ditiru oleh anak buahnya. Pemimpin merupakan driver dari inisiatif kualitas, sehingga kepemimpinan yang tidak stabil dapat mengarah pada hasil yang tidak diinginkan. Hal lain adalah sikap karyawan terhadap kualtias yang menjadi salah satu tantangan terbesar, karena sangat sulit untuk mengubah mindset karyawan berkaitan dengan kualitas. Mereka megatakan bahwa kualitas itu berarti peningkatan biaya, sehingga dengan demikian tidak dapat diterima sebagai bagian integral dari pekerjaan.

\section{Kesimpulan}

Negara Jepang merupakan salah satu negara maju di Asia dengan tidak meninggal kan ciri khas dan nasionalisme negara Jepang itu sendiri, meskipun orang Jepang membuat perusahaan dan menjalankan bisnis dan perekonomian di negara lain, tetapi nilai-nilai nasionalisme Jepang tetap dipegang teguh dan tetap dilaksanakan dalam segala bidang yang mereka lakukan. Dalam hal pelaksanaan ekonomi dan bisni, orang Jepang lebih mengedepankan pada sumber daya manusia dalam perusahaan maupun organisasi yang mereka bentuk dan mereka jalankan. Total Quality Management yang mengikat pada perusahaan Jepang tidak terlepas dari budaya Kaizen, sehingga Jepang lebih menerapkan prinsip Kepuasan Pelanggan, Quality Function Development (QFD), Pemberdayaan Karyawan, Perbaikan Berkesinambungan dalam perusahaannya.

Pengembangan produk yang dilakukan perusahaan Jepang adalah memenuhi segmen pasar dengan standar internasional serta pada sisi kualitas dalam produk. Kegagalan dalam melakukannya dapat mengakibatkan denda besar dan pencitraan pers yang buruk yang akan 
merusak reputasi perusahaan. Perbaikan terus menerus di berbagai bidang, menghormati, dan kerja sama tim adalah kunci kesuksesan Total Quality Management dalam perusahan Jepang. Perusahaan-perusahaan Jepang diidentifikasi memiliki time horizon jangka panjang.

\section{Rekomendasi}

Perusahaan-perusahaan di Indonesia dapat mempelajari dari success story maupun best practice yang terdapat pada perusahaan Jepang maupun perusahaan-perusahaan di negara lain yang berhasil mengadopsi TQM. Selain itu, setelah mengetahui faktor-faktor penting yang dapat mendukung kesuksesan maupun kegagalan dalam efektivitas implementasi TQM, maka akan bermanfaat apabila perusahaan-perusahaan yang ada di Indonesia dapat memaksimalkan faktor-faktor penunjang tersebut. Sebaliknya, perbaikan secara berkesinambungan pun harus senantiasa dilaksanakan untuk meminimalkan hambatan yang terjadi.

\section{Refferensi}

Amar, Kiyafah \& Zuraidah Mohd Zain. (2001). Barriers in the Implementation of Total Quality Management in Indonesian Manufacturing Organizations. Jurnal Teknik Industri, Vol. 3, No. 2, Desember 2001: 72-79.

Banker, R., G. Potter, dan R. Schroeder. 1993. Exporting Manufacturing Performance Measures To Worker: An Empirical Study. Journal of Management Accounting Research: 33-35.

Cane, 1998. Establishing Kaizen Culture, Circuit Assemble, November.

Daniel, S., dan W. Reitsperger. 1991. Linking Quality Strategy With Management Control Systems: Empirical Evidence From Japanese Industry. Accounting, Organizations and Society $17: 601-618$

Dowling, P. \& Welch, D. E. (2004) International Human Resource Management: Managing People in a Multinational Context 4th edition, London UK, Thomson Learning.

Dowling, Peter J, Marion Festing and Allen D. Engle, 2008. International Human Resource Management : Managing People in a Multinational Context : Fifth Edition, SouthWestern Cengage Learning, United Kingdom

Gaspersz, Vincent. 1998. Manajemen Produktivitas Total. Jakarta.Gramedia Pustaka Utama.

Gaspersz, Vincent. 2001. Total Quality Management. Jakarta : Gramedia Pustaka Utama.

Handayani, 2005. Kaizen Culture, Education and Training, New York: Irwing Professional

Hansen, Don R. and Mowen Maryanne M. 2000. Management Accounting. Cincinnati Ohio: South-Western College Publishing.

Hari Purnomo, Pengantar Teknik Industri, Graha Ilmu 2004, Yogyakarta.

Hitoshi Takeda, 2006. The Change Management Handbook, New York: Irwing Professional 
Horngren, Charles T., George Foster., Srikant M. Datar. 2000. Cost Accounting: A Managerial Emphasis. International Edition.

Jurnal Akuntansi Vol.4 No.2 November 2012: 175-186. Pengaruh Penerapan Total Quality Management (TQM) dan Komitmen Organisasi terhadap Kinerja Perusahaan dengan Budaya Organisasi Sebagai Variabel Moderasi (Survei padaPerusahaan Manufaktur di Jawa Barat yang Listing di BEI)

Jurnal Akuntansi, Vol. 1, No. 2, April 2013 : 213-226. ISSN 2337-4314. Pengaruh Total Quality Management Terhadap Kinerja Financial (Study Pada Perusahaan Jasa di Kota Pekanbaru Provinsi Riau)

Krajewski, J. Lee and P. R. Larry, 2006, Operations Management Strategy and Analysis, Fifth Edition, Addison-Wesley Publising Company Inc.

Kujala, J., \& Lillrank, P. (2004). Total quality management as a cultural phenomenon. Quality Management Journal, 11(4), 43-55.

Lincoln, J. R. (1989). Employee work attitudes and management practice in the US and Japan. California Management Review(Fall), 89-106.

Locke,E., dan G. Latham. 1990. Goal Setting Theory and Task performance”. New York: Prentice Hall.

Masaaki Imai. 1998. Genba Kaizen : Pendekatan Akal Sehat, Berbiaya Rendah Pada Manajemen. Jakarta, Pustaka Brinaman Pressindo.

Majalah Ekonomi Tahun XVII, No.2 Agustus 2007. Total Quality Management, Sistem Pengukuran Kinerja, Sistem Penghargaan Dan Kinerja Manajerial

Martin Fackler, - In Toyota Mess, Lesson for Japan”, The New York Times, 8 Februari 2010 (http://www.nytimes.com/2010/02/09/business/global/09toyota.html)

Masaaki Imai. 1991. Kaizen : The Key to Japan's Competitive Success. Singapore, McGrawHill International

Masaaki Imai. 1998. Genba Kaizen: Pendekatan Akal Sehat, Berbiaya Rendah Pada Manajemen. Jakarta, Pustaka Brinaman Pressindo.

Motwani, Jaideep (2001). Critical Factors and Performance Measures of TQM, The TQM Magazine, 13(4), $292-300$

Nilda Tri Putri \& Sha'ri Mohd Yusof. (2008). Critical Success Factors for Implementing Quality Engineering (QE) In Malaysian's and Indonesian's Automotive Industries: A Proposed Model. 2008, Korea Automotive Research Institute. IJAIM, Vol. 2 (December 2008), 1-15

Noguchi, J. (1995). The legacy of W. Edwards Deming. Quality Progress, 28(12), 35-37.

Prajogo D.I., A.S. Sohal (2000) TQM and innovation: A literature review and research framework, Technovation hal 539-558 
Poropat, Arthur \& John Keller. (n.d). Buddhism and TQM: An Alternative Explanation of Japan's Adoption of Total Quality Management. Department of Management, Griffith Business School, Griffith University, Australia.

Prajogo, Daniel. I., and Brown, A. 2004. "The Relationship Between TQM Practice and Quality Performance and the Role of Formal TQM Programs: An Australian Empirical Study”. Quality Management Journal. 11 (4), pp.31-42

Reader, I., Andreasen, E., \& Stafansson, F. (1993). Japanese religions: Past and present. Honolulu: University of Hawaii Press.

Sila, I. 2007. Examining the effects of contextual faktors on TQM and performance through the lens of organizational theory: an empirical study, Journal of Operations Management, Vol. 25, No. 1, pp. 83-109.

Sisnuhadi. (2014). The Relationship between Soft Factors and Hard Factors of TQM Practices and Organizational Learning. European Scientific Journal, March 2014 edition, vol. 10, Mo. 7.

The Influence of Total Quality Management (TQM) Applications to Sales Raising at PT. Kereta Api Indonesia (Persero) Bandung The 2nd Operations Area. ISBN: 978-97999365-7-8.

Tjiptono, Diana, 2003, Total Quality Management, Andi Yogyakarta.p.15-18

http://www.perkuliahan.com/apa-pengertian-studi-kepustakaan/\#ixzz38S9TsEC3 